\title{
BOTULINUM TOXIN A FOR TRISMUS IN CEPHALIC TETANUS
}

\author{
LUIZ AUGUSTO F.ANDRADE*, SONIA MARIA D.BRUCKI**
}

\begin{abstract}
SUMMARY - Cephalic tetanus is a localized form of tetanus. As in generalized forms, trismus is a prominent feature of the disease, leading to considerable difficulty in feeding, swallowing of the saliva and mouth hygiene. These difficulties often precede respiratory problems and aspiration bronchopneumonia is a frequent lifethreatening complication. Muscle relaxants other than curare drugs may show a limited benefit for relieving trismus. Tetanospasmin, the tetanic neurotoxin, and botulinum toxin share many similarities, having a closely related chemical structure, an origin from related microorganisms (Clostridium tetani and Clostridium botulinum, respectively), and presumably, the same mechanisms of action in the neuron. The difference between the two lies in their peculiar neurospecificity, acting in different neurons. Injection of minute doses of botulinum toxin in the muscles involved in focal dystonias or other localized spastic disorders have proved to be very effective in these conditions. We describe the use of botulinum toxin A in the successful treatment of trismus in a patient suffering from cephalic tetanus. We believe that this form of treatment may be of value in lowering the risk of pulmonary complications in tetanic patients.
\end{abstract}

KEY WORDS: tetanus, cephalic tetanus, trismus, botulinum toxin A.

\section{Toxina botulínica A para o trismo no tétano cefálico}

RESUMO - O tétano cefálico é uma forma localizada de tétano. Da mesma maneira que nas formas generalizadas, o trismo é componente clínico proeminente, que leva a grande dificuldade na alimentação, na deglutição da saliva e para a higiene da boca. Essas dificuldades frequentemente precedem os problemas respiratórios e as pneumonias aspirativas, que se constituem em complicações que ameaçam a vida dos pacientes. Drogas relaxantes musculares de outro tipo que as drogas curarizantes trazem pouco benefício para o trismo. A neurotoxina tetânica (tetanospasmin) e a toxina botulínica compartilham muitas semelhanças, como estrutura química símile, origem de microorganismos relacionados (Clostridium tetani e Clostridium botulinum, respectivamente) e, presumivelmente, os mesmos mecanismos de ação no neurônio. A diferença entre as duas reside na sua peculiar neuroespecificidade, atuando em diferentes neurônios. Injeção de doses reduzidas da toxina botulínica em músculos envolvidos em distonias focais ou outras desordens com espasticidade muscular localizada tem se mostrado eficaz em abolir as contrações. Descrevemos o uso da toxina botulínica A com sucesso no tratamento do trismo num paciente sofrendo de tétano cefálico. Acreditamos que esta forma de tratamento possa ser de valor no sentido de diminuir o risco de complicações pulmonares nos pacientes com tétano.

PALAVRAS-CHAVE: tétano, tétano cefálico, trismo, toxina botulínica A.

Cephalic tetanus is an unusual, localized form of tetanus. The disease is caused by the action of a neurotoxin, tetanospasmin (TS), which is produced by Clostridium tetani. Although a rare disease in civilized countries, tetanus still remains as a concern in developing and under civilized countries, owing to the great number of cases. Neonates and unimmunized or inadequately immunized children and young adults are more prone to the disease $e^{3,8}$. Most cases present as generalized tetanus.

Movement Disorders Division, Department of Neurology and Neurosurgery, Escola Paulista de Medicina: *Associate Professor; **Postgraduate. Aceite: 10 -janeiro-1994.

Dr. Luiz Augusto Franco de Andrade - Disciplina de Neurologia, Escola Paulista de Medicina - Rua Botucatu 740 -04023-900 - São Paulo SP - Brasil. 
TS entries the nervous system predominantly at the myoneural junctions of the alpha motor neurons and an axonal retrograde transport carries the neurotoxin to the central nervous system ${ }^{2}$. Three different levels may be affected by TS: motor control cells in the brainstem or in the spinal cord, autonomic cells in different parts of the autonomic system and the neuromuscular junction. Presynaptic inhibitory cells, utilizing either glycine or GABA as inhibitory neurotransmitters, in the spinal cord and brainstem are target cells to TS. More details on the pathophysiology, management and prophylaxis of tetanus may be found in a recent review by Bleck ${ }^{1}$. Despite considerable improvement in the management of respiratory complications, with more effective muscle relaxants, sophisticated mechanical respiratory devices, new antibiotics and better intensive care, fatal outcomes are still seen in many cases. Bronchopneumonia, mainly due to aspiration is highly prevalent. Trismus may be a particular contributing mechanical factor that enhances aspiration, in addition to swallowing difficulty. Curare drugs have been considered the only effective drugs for abolishing the spasms.

The botulinum toxin (botox), another potent neurotoxin, produced by the Clostridium botulinum is very similar to TS. Its site of action is predominantly the synaptic terminal of the cholinergic lower motor neuron. TS and botox share a very similar chemical structure, the same mechanisms of action, strong potency but different neurospecificity. Opposed to TS, botox causes flaccid paralysis due to neuroexocytosis block at the neuromuscular junction ${ }^{6}$. Localized injections of minute doses of botulinum toxin A has been successfully used for the treatment of different conditions where muscular spasms predominate, as in focal dystonias (blepharospasm, cervical, oro-mandibular and laryngeal dystonias, writers cramp), hemifacial spasm and other similar conditions.

In a recent case of cephalic tetanus we had the opportunity of treating the trismus with botulinum toxin A, thus improving the patient's respiratory distress, allowing proper mouth hygiene and secretion aspiration, as well as returning him to a much more confortable feeding condition.

\section{CASE REPORT}

JNS (RG.811551), male, 33 years-old, black, was admitted to Hospital São Paulo on November, 23rd., 1992. Eight days before, working in a building construction, he had a fall banging his forehead on the ground and producing an open wound in his nose bridge. On that same day he was treated, receiving a tetanic antitoxin dose and penicillin. We could not obtain further details concerning these medications. He was well until three days before admission, when he started having difficulty, soon followed by incapacity to open his mouth and swallowing troubles. His previous medical history was unremarkable. In the admission examination an infected open wound in the nose bridge was clear. The patient temperature was normal, as well as all other clinical parameters. A pronounced trismus was present rendering him unable to open his mouth, with clenched teeth. On palpation, the masseter muscles were tense, hypertonic. There were signs of bilateral facial paresis, as seen by lid lag on both eyes. Owing to the dysphagia and the great difficulty of swallowing of his own saliva, along with the impossibility of opening his mouth, the patient presented respiratory distress and choking. Neck movements were difficult, but all other parts of the body could be easily voluntarily moved. No muscle power deficits could be found in these other body segments. Except for the cranial and cervical segment the muscle tone was normal. The rest of the clinical and neurological examination was entirely normal. The patient was transferred to the ICU and received human tetanic immunoglobulin (TIG), $250 \mathrm{U}$ locally in the wound and 4500 U IM. A high dose penicillin regimen was started, with a daily dose of 24 million units. A nasogastric feeding tube was inserted.

The diagnosis of cephalic tetanus was clearly obvious and, as usual for tetanus, an early tracheostomy was performed. He was put under diazepam, in escalating doses, up to $240 \mathrm{mg} / \mathrm{day}$, to control intense muscle spasms in his throat and mouth. Few days after being admitted he developed a pneumonia and started receiving cyprofloxacin and ceftazidime in proper amounts. On day 15 of his stay at the ICU his clinical condition had deteriorated. Although the pneumonia had subsided he was having trouble with the mechanical ventilator, and the medical staff was considering utilizing curare drugs on him. All his difficulties and the excessive manipulations he had been submitted would drive him to further pulmonary infections.

At this stage we decided to treat the trismus with botulinum toxin A (botox). Thirty units were injected directly into the bulk of the masseter muscle on either side (in two separate sites) and an additional 20 units dose was injected in the more anterior part of this muscle (one site), again on either side. 
Three days after the botox injection the patient experienced a subjective improvement of mouth opening, although no clear separation of his teeth could be seen. Four days later, he was able to slightly open his mouth, with $0.5 \mathrm{~cm}$ separation between the upper and lower dental arcades. Ten days after botox he was able to open his jaw keeping his teeth $1 \mathrm{~cm}$ separated. By then, the feeding nasogastric tube was removed, his mouth hygiene could be easily made and swallowing became more effective. When he completed two weeks after botox his mouth could open widely. A clear atrophy of both masseter muscles was visible. He was discharged from the hospital and followed at the outpatient clinic. One month later he came to a routine visit when his examination showed normal findings, but his masseter muscles were still atrophied, although he could open and close normally the jaw.

\section{COMMENTS}

Botulinum toxin and TS are among the more potent neurotoxins existing in nature. The term botulinum toxin stands for eight substances belonging to seven different serotypes $(A, B, C 1, C 2, D$, $\mathrm{E}, \mathrm{F}$ and G). C2 is a binary toxin. The other seven, known as the botulinum neurotoxins and TS are produced by two toxigenic strains of Clostridium, the botulinic and tetanic, respectively. They share very similar biochemical structures. Two polypeptide chains, a heavy $(100 \mathrm{kDa})$ and a light $(50 \mathrm{kDa})$ with an interchain disulfide bond forms the active neurotoxins ${ }^{5,6}$. The synthesis and proteolytic cleavage is identical to both neurotoxins ${ }^{6}$. Slight changes in aminoacid sequence make their different neurospecific targetting ${ }^{7}$. TS causes a spastic paralysis due to its blocking action on inhibitory interneurons of the brainstem and spinal cord (glycine and GABA neurons). Botox causes a flaccid paralysis, blocking neuromuscular transmission presynaptically. Acetylcholine release (exocytosis), specifically at the lower motor neuron terminal is blocked by the toxin. Although acting in different target neurons, the toxins share the same basic action mechanisms; binding, internalization and intracellular poisoning steps are alike.

When we decided to use botox in order to treat the trismus in our patient, the aim was to produce a long lasting "curare-like" localized effect on the masseters. We had some concern in the use of botox in a patient suffering from a serious disease produced by a very similar potent neurotoxin. To our knowledge no other case of tetanus, in any form, had been treated like this before. As far as we could search in the literature, there has been no mention to the simultaneous use of both neurotoxins in a single animal. We received an approval of the ethics committee of our institution before making the injections.

There is considerable variation in the natural course of tetanus. Generalized forms carry a greater risk for life and the duration of the muscle spasms may vary widely, up to 44 days $^{3}$, and in our institution even longer duration has been seen. Patients requiring respirator treatment may have the poorest outcome $e^{4}$. Cephalic tetanus, although being considered a more benign form of the disease may, as well, vary greatly in the duration of the trismus and the other manifestations of muscular overactivity. In the present case the improvement in jaw opening began few days after the botox injection, as it would be expected for a similar treatment in other conditions. In the natural course of tetanus an improvement of the muscle spasm in other muscle groups going along with that of the masseters would be expected. The rapid and disproportional improvement of the masseters as compared to pharyngeal and face muscles in our case made us quite sure that botox had been useful for the patient. A further confirmation of the muscular effect was the atrophy which was produced in the masseters. We think that botox may be very useful in the treatment of trismus in tetanic patients. The possibility of lowering the risk of pneumonia and the improvement in oral hygiene and feeding conditions in patients suffering from tetanus are the mainstem of this new application of botulinum toxin A.

Acknowledgement - This work was supported in part by a grant from CAPES and CNPq. Botox ${ }^{\mathrm{R}}$ was kindly offered by Allergan.

\section{REFERENCES}

1. Bleck TP. Tetanus: pathophysiology, management and prophylaxis. Dis Mon 1991, 37: 545-603. 
2. Cate TR. Clostridium tetani (tetanus). In Principles and practice of infeccious diseases. Ed 3. Mandell GL, Douglas RG, Benett JE (eds) New York: Churchill Livingstone, 1990, p 1842-1846.

3. Edmondson RS, Flowers MW. Intensive care in tetanus: management, complications, and mortality in 100 cases. Br Med J 1979, 1: 1401-1404.

4. Luisto M. Outcome and neurological sequelae of patients after tetanus. Acta Neurol Scand 1989, 80: 504-511.

5. Schiavo G, Boquet P, Dasgupta BR, Montecucco C. Membrane interactions of tetanus and botulinum neurotoxins: a photolabelling study with photoactivatable phopholipids. J Physiol (Paris) 1990, 84: 180-187.

6. Simpson LL. Molecular pharmacology of botulinum toxin and tetanus toxin. Ann Rev Pharmacol Toxicol 1986, 26: 427-453.

7. Singh BR. Identification of specific domains in botulinum and tetanus neurotoxins. Toxicon 1990, 28: 992-996.

8. Weinstein L. Tetanus. N Engl J Med 1973, 289: 1293-1296. 